Correspondence

Tomohiko Kuwabara kuwabara@biol.tsukuba.ac.jp

\section{Thermosipho globiformans sp. nov., an anaerobic thermophilic bacterium that transforms into multicellular spheroids with a defect in peptidoglycan formation}

\author{
Tomohiko Kuwabara, ${ }^{1,2}$ Akitomo Kawasaki, ${ }^{2} \dagger$ Ikuko Uda ${ }^{3}$ \\ and Akihiko Sugai ${ }^{3}$ \\ ${ }^{1}$ Graduate School of Life and Environmental Sciences, University of Tsukuba, Tsukuba 305-8572, \\ Japan \\ ${ }^{2}$ College of Biological Sciences, University of Tsukuba, Tsukuba 305-8572, Japan \\ ${ }^{3}$ Division of Chemistry, College of Liberal Arts and Sciences, Kitasato University, Sagamihara \\ 228-8555, Japan
}

\begin{abstract}
An anaerobic rod-shaped thermophile was isolated from a hydrothermal vent at Suiyo Seamount, Izu-Bonin Arc, western Pacific Ocean, and was named strain MN14 ${ }^{\top}$. The rods were Gramnegative-staining, non-motile without flagella, 2-4 $\mu \mathrm{m}$ long and $0.5 \mu \mathrm{m}$ wide, and divided by binary fission in the mid-exponential phase. The cells were surrounded by a sheath-like structure (toga) and occurred singly or in chains. Spheroids containing multiple cells were observed not only in the stationary phase, as previously observed for species of the order Thermotogales, but also from the early exponential phase. Transmission electron microscopy revealed that the peptidoglycan in rods partly disintegrated in the early growth phases and that the outer membrane of the spheroids was not completely lined with peptidoglycan. These findings suggested that the spheroids were formed from rods by the disintegration of peptidoglycan and subsequent inflation of the outer membrane. The spheroids eventually generated tiny cells in the periplasmic space, indicating a viviparous mode of proliferation in addition to binary fission. Strain $\mathrm{MN} 14^{\top}$ grew at 40-75 ${ }^{\circ} \mathrm{C}$, pH 5.0-8.2 and with $0.25-5.20 \%(\mathrm{w} / \mathrm{v}) \mathrm{NaCl}$, with optimal growth occurring at $68{ }^{\circ} \mathrm{C}, \mathrm{pH} 6.8$ and with $2.5 \% \mathrm{NaCl}$. The shortest doubling time was $24 \mathrm{~min}$, assuming that the strain propagated only by binary fission. Elemental sulfur enhanced growth, but was not essential. Thiosulfate was not an electron acceptor for growth. The strain was a chemo-organotroph that grew on yeast extract as the sole growth substrate. Tryptone and starch supported its growth in the presence of yeast extract. The $G+C$ content of the genomic DNA was $31.7 \mathrm{~mol} \%$.

Phylogenetic analysis based on the 16S rRNA gene sequence indicated that this strain belonged to the genus Thermosipho. No significant DNA-DNA hybridization was observed between the genomic DNA of strain $\mathrm{MN} 14^{\top}$ and phylogenetically related species of the genus Thermosipho. Based on this evidence, strain $\mathrm{MN} 14^{\top}$ is proposed to represent a novel species, named Thermosipho globiformans sp. nov. The species epithet globiformans reflects the formation of multicellular and reproductive spheroids by the novel strain. The type strain of this species is MN14 ${ }^{\top}\left(=\right.$ JCM $15059^{\top}=$ DSM $\left.19918^{\top}\right)$.
\end{abstract}

tPresent address: Faculty of Agriculture, Food and Natural Resources, The University of Sydney, Eveleigh NSW 2015, Australia.

Abbreviation: TEM, transmission electron microscopy.

The GenBank/EMBL/DDBJ accession number for the 16S rRNA gene sequence of Thermosipho globiformans sp. nov. MN14 ${ }^{\top}$ is AB257289.

Supplementary figures and a movie are available with the online version of this paper.
The genus Thermosipho belongs to the order Thermotogales, the members of which are rod-shaped bacteria that are morphologically characterized by an outer sheath-like structure called a toga (Huber \& Stetter, 1992). The order Thermotogales is an enigmatic taxon that is highly susceptible to lateral gene transfer from members of the Firmicutes and Archaea (Nelson et al., 1999; Nesbø et al., 2009). However, it is not known how the toga is related to the susceptibility of these micro-organisms to lateral gene 
transfer. At the time of writing, five species of the genus Thermosipho have been reported: Thermosipho africanus, isolated from a hot spring in a tidal zone (Huber et al., 1989; Ravot et al., 1996), Thermosipho melanesiensis, from the gills of deep-sea hydrothermal mussels (Antoine et al., 1997), Thermosipho japonicus, from a deep-sea chimney (Takai \& Horikoshi, 2000), Thermosipho geolei, from a deep-sea oil reservoir (L'Haridon et al., 2001) and Thermosipho atlanticus, from a deep-sea hydrothermal vent (Urios et al., 2004). In this paper, we describe a novel strain, $\mathrm{MN} 14^{\mathrm{T}}$, which was isolated from a hydrothermal vent of Suiyo Seamount. A population of this strain was found to transform to multicellular spheroids because of a defect in peptidoglycan formation. The spheroids eventually generated tiny cells in the periplasmic space.

Thermophilic micro-organisms were cultivated in situ for 2 days at a hydrothermal vent at Suiyo Seamount, IzuBonin Arc, western Pacific Ocean (28 $\left.34^{\prime} \mathrm{N} 140^{\circ} 38^{\prime} \mathrm{E}\right)$, at a depth of $1384 \mathrm{~m}$, using an in situ cultivation device (Kuwabara et al., 2006). The device was conveyed to the in situ cultivation site by a remotely operated vehicle HyperDolphin [Japan Agency for Marine-Earth Science and Technology (JAMSTEC)] during the NT05-16 cruise (22 September -7 October, 2005) of the R/V Natsushima (JAMSTEC). The device was designed to form interfaces between hot-and-anaerobic hydrothermal fluid and cooland-aerobic seawater above the seabed, and contained dacite pumice and apatite as solid matrices for cultivation. The in situ temperature of the hydrothermal fluid was $230{ }^{\circ} \mathrm{C}$ and the temperature of the fluid being emitted from the device was $25{ }^{\circ} \mathrm{C}$, which suggested that the interfaces were formed in the device. After the in situ cultivation step, the device was transferred to the mother ship and the matrices were packed anaerobically (Kuwabara et al., 2005) and transported to the laboratory. A dacite pumice matrix was ground using a sterilized mortar and pestle in an anaerobic workstation in which the gas phase was $80 \mathrm{~N}_{2}: 10$ $\mathrm{H}_{2}: 10 \mathrm{CO}_{2}$ (Kuwabara et al., 2005). Approximately $0.1 \mathrm{~g}$ ground matrix was inoculated into $2 \mathrm{ml}$ TF medium $(\mathrm{pH} 7.0)$ in a $14 \mathrm{ml}$ serum bottle. The TF medium contained $\left(\mathrm{l}^{-1}\right): 25 \mathrm{~g} \mathrm{NaCl}, 0.33 \mathrm{~g} \mathrm{KCl}, 2.8 \mathrm{~g} \mathrm{MgCl}_{2} .6 \mathrm{H}_{2} \mathrm{O}$, $3.4 \mathrm{~g} \mathrm{MgSO}_{4} .7 \mathrm{H}_{2} \mathrm{O}, 10 \mathrm{mg} \mathrm{NaBr}, 0.3 \mathrm{~g} \mathrm{~K}_{2} \mathrm{HPO}_{4}, 0.25 \mathrm{~g}$ $\mathrm{NH}_{4} \mathrm{Cl}, 4.8 \mathrm{~g} \mathrm{Fe}_{2} \mathrm{O}_{3}, 10 \mathrm{ml}$ trace mineral solution and $10 \mathrm{ml}$ vitamin solution (Balch et al., 1979), $3 \mathrm{~g}$ yeast extract, $3 \mathrm{~g}$ tryptone, $0.5 \mathrm{~g} \mathrm{Na} \mathrm{S}_{2} \mathrm{~S} .9 \mathrm{H}_{2} \mathrm{O}$ and $1 \mathrm{mg}$ resazurin. Anaerobic cultivation was performed at $55{ }^{\circ} \mathrm{C}$ for $20 \mathrm{~h}$ (Kuwabara et al., 2005). Large spheroids, in which globular cells emitted intense epifluorescence, were grown together with rods and cocci. Purification of the spheroids was performed by the dilution-to-extinction method and then by repeated single-colony isolation at $55{ }^{\circ} \mathrm{C}$ with plates containing $0.8 \%$ Gelrite in $\mathrm{TF}$ medium under anaerobic conditions (Kuwabara et al., 2005). Single colonies were obtained after 3 days of incubation. Even after purification, the spheroids could not be separated from the rods and were later shown to be different forms of the same organism. Four colonies were individually liquid-cultured and one colony that produced multicellular spheroids most frequently in the lag to early exponential phases was selected. The purified strain was named strain $\mathrm{MN}^{\mathrm{T}}{ }^{\mathrm{T}}$, in which MN stands for 'multinucleated'. Strain $\mathrm{MN} 14^{\mathrm{T}}$ was found to grow better in Tc medium ( $\mathrm{pH}$ 6.8) (Kuwabara et al., 2005), which contained $\mathrm{Fe}_{2} \mathrm{SO}_{4}\left(25 \mathrm{mg} \mathrm{l}^{-1}\right.$ ) and elemental sulfur $\left(10 \mathrm{~g} \mathrm{l}^{-1}\right)$, than in TF medium that instead contained $\mathrm{Fe}_{2} \mathrm{O}_{3}$. For successive cultivations, strain $\mathrm{MN} 14^{\mathrm{T}}$ was grown in Tc medium at $68{ }^{\circ} \mathrm{C}$ for $12 \mathrm{~h}$ and stored at $4{ }^{\circ} \mathrm{C}$, unless otherwise stated. These cultures remained effective as inocula for at least 3 months. For longer storage, the cultures were frozen in $15 \%(\mathrm{v} / \mathrm{v})$ glycerol at $-80{ }^{\circ} \mathrm{C}$.

Thermosipho africanus DSM $5309^{\mathrm{T}}$ was purchased from Deutsche Sammlung von Mikroorganismen und Zellkulturen (DSMZ) and was cultivated in DSM medium 483 in the presence of $20 \mathrm{mM}$ sodium thiosulfate (Ravot et al., 1996). Thermosipho japonicus JCM $10495^{\mathrm{T}}$ was obtained from the Japan Collection of Microorganisms (JCM) and cultivated in JCM medium 261.

Epifluorescence microscopy was performed using a LIVE/ DEAD BacLight Bacterial Viability kit (L-7007, Molecular Probes; hereafter termed Live/Dead), unless otherwise stated. FM1-43 dye (Molecular Probes) and acridine orange were also used for observation of membranes and for direct counting of cells, respectively.

Transmission electron microscopy (TEM) was performed as follows. Cultures were centrifuged at $50 \mathrm{~g}$ for $5 \mathrm{~min}$ to remove debris and elemental sulfur. Cells were collected by centrifugation at $1670 \mathrm{~g}$ for $20 \mathrm{~min}$. The precipitates were suspended in $2 \mathrm{ml} 2 \% \mathrm{NaCl}$ and centrifuged at $50 \mathrm{~g}$ for $5 \mathrm{~min}$. The supernatant was mixed with an equal volume of $4 \%$ (to observe rods) or $15 \%$ (to observe spheroids) glutaraldehyde in $0.2 \mathrm{M}$ sodium cacodylate buffer ( $\mathrm{pH} 7.2)$ and the mixture was incubated at room temperature (to observe rods) or at $4{ }^{\circ} \mathrm{C}$ (to observe spheroids) for $2 \mathrm{~h}$. The samples were centrifuged at $740 \mathrm{~g}$ for $10 \mathrm{~min}$ at room temperature. The precipitates were washed with cacodylate buffer and post-fixed with $1 \%$ osmium tetroxide in cacodylate buffer at room temperature for $1 \mathrm{~h}$. Fixed cells were sedimented using a hand-operated portable centrifuge and the supernatant was discarded by decantation. The sediments were washed three times with cacodylate buffer by hand-operated centrifugation and decantation. The samples were dehydrated with ethanol, treated with propylene oxide, embedded in Spurr's resin, thin-sectioned and observed under TEM (JEM1010; JEOL), as described previously (Kuwabara et al., 2007).

Acid methanolysis of fatty acids and TLC of the resulting fatty acid methyl esters were performed essentially according to Takai \& Horikoshi (2000). Spots on the TLC plate were quantified in terms of optical density at $600 \mathrm{~nm}$ by using a chromatoscanner (CS-930; Shimadzu). The monocarboxylic fatty acid methyl esters obtained were subjected to GLC in an SP-2560 capillary column $\left(100 \mathrm{~m} \times 0.25 \mathrm{~mm}\right.$ i.d.; $d_{\mathrm{f}}, 0.2 \mu \mathrm{m}$; Supelco $)$ at a split ratio 
of $49: 1$. This column was coupled to a Shimadzu GC-2014 instrument equipped with a flame-ionization detector in which hydrogen gas and air were used. Helium was used as the carrier gas. The analyses were initially performed at a temperature of $140{ }^{\circ} \mathrm{C}$ for $5 \mathrm{~min}$, which was then increased to $240{ }^{\circ} \mathrm{C}$ at a rate of $4{ }^{\circ} \mathrm{C} \mathrm{min}{ }^{-1}$. Both the injector and detector were set at $260{ }^{\circ} \mathrm{C}$. The monocarboxylic fatty acid methyl esters were identified by comparing their retention times with those of authentic fatty acid methyl ester standards (Supelco 37 Component FAME Mix from Supelco and Mix BR2, Mix BR3 and Mix BR4 from Larodan Fine Chemicals AB). Fatty acid compositions were calculated from the peak areas.

Genomic DNA was prepared as previously described (Wilson, 2002). The 16S rRNA gene was PCR-amplified using genomic DNA with the primers 9F (Kim et al., 2004) and 1406R (Yoon et al., 1998). PCR was performed using PrimeSTAR HS DNA polymerase (TaKaRa Bio) with 30 cycles of denaturation at $98{ }^{\circ} \mathrm{C}$ for $10 \mathrm{~s}$, annealing at $57{ }^{\circ} \mathrm{C}$ for $5 \mathrm{~s}$ and extension at $72{ }^{\circ} \mathrm{C}$ for $60 \mathrm{~s}$ or by using the MicroSeq $50016 \mathrm{~S}$ rRNA bacterial sequencing kit (Applied Biosystems) according to the manufacturer's protocol. The amplified DNA was sequenced using the primers $5 \mathrm{~F}$ (from the MicroSeq kit), 9F (Kim et al., 2004), 907F (Lane et al., 1985), 1114f (Elbanna et al., 2003), 536R (from the MicroSeq kit), 926R (Yoon et al., 1998) and 1406R (Yoon et al., 1998). The $\mathrm{G}+\mathrm{C}$ content of the DNA was determined as described by Katayama-Fujimura et al. (1984). For DNA-DNA hybridization, genomic DNA was prepared as described by Wilson (2002), except that the extraction medium contained 0.4 M EDTA and the cetyl trimethyl ammonium bromide treatment was performed at room temperature. These modifications prevented degradation/modification of DNA by the Fenton reaction. After chloroform-isoamyl alcohol precipitation, DNA was purified by ultracentrifugation in CsCl. Microplate DNA-DNA hybridizations were performed as described previously (Kuwabara et al., 2007).

Cells of strain $\mathrm{MN} 14^{\mathrm{T}}$ were rod-shaped. The rods were Gram-negative staining, non-motile without flagella, 2$4 \mu \mathrm{m}$ long and $0.5 \mu \mathrm{m}$ wide, and divided by binary fission in the mid-exponential phase (Fig. 1 and unpublished hightemperature microscopy data). The cells occurred singly or in chains and were surrounded by a toga. However, a population of rods transformed to spheroids during the lag and early exponential phases. Spheroids grew in the later phases and this was accompanied by transformation of cells (see Supplementary Fig. S1 in IJSEM Online). Spheroid formation has been reported for many species of the order Thermotogales in the stationary phase, but never in the early growth phases. The spheroids eventually produced tiny cells in the periplasmic space in the late exponential phase (see the Supplementary movies in IJSEM Online). The tiny substances were identified as cells because they were stained with FM1-43 dye as well as with Live/Dead, indicating that they had membranes and nucleic acids, respectively. The observed viviparity was

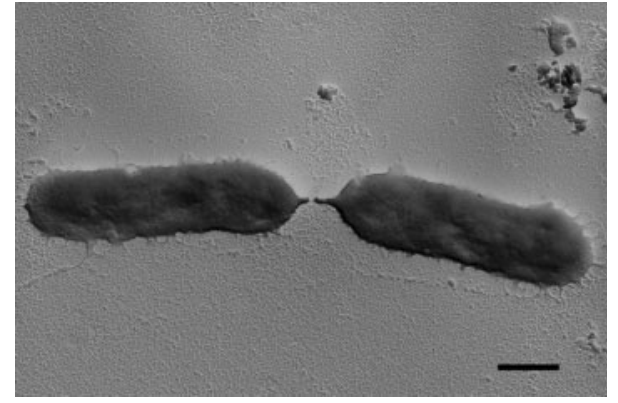

Fig. 1. Shadowing of cells of strain $M N 14^{\top}$. Cells in the late exponential phase were fixed on a Formvar-coated grid with $2.5 \%$ glutaraldehyde in $0.2 \mathrm{M}$ sodium cacodylate buffer $(\mathrm{pH} 7.2)$ and were shadow-cast with a platinum-palladium alloy, as described previously (Fiala \& Stetter, 1986). Bar, $500 \mathrm{~nm}$.

similar to that of some cyanobacteria that produce baeocytes (Waterbury \& Stanier, 1978). When the rods in the mid-exponential phase (see Supplementary Fig. S1h) were treated with $1 \mathrm{mg} \mathrm{ml}^{-1}$ of lysozyme, which hydrolyses peptidoglycan, small spheroids similar to those observed in the early exponential phase (Supplementary Fig. S1c) were generated within a few minutes (Huber et al., 1990). This suggests that spheroid formation is related to the disintegration of peptidoglycan (Satta et al., 1979; Bendezú \& de Boer, 2008).

TEM revealed that the outer membranes of the rods were fully lined with peptidoglycan even at the blebs at both tips of the rods. A rod in the early exponential phase, which demonstrates local disintegration of lateral peptidoglycan and partial inflation of the outer membrane, is seen in Fig. 2a. This finding suggests that disintegration of peptidoglycan caused the inflation of the outer membrane. Fig. $2 b$ clearly shows that the spheroid is multicellular, containing cells with different sizes and shapes, and that the spheroid
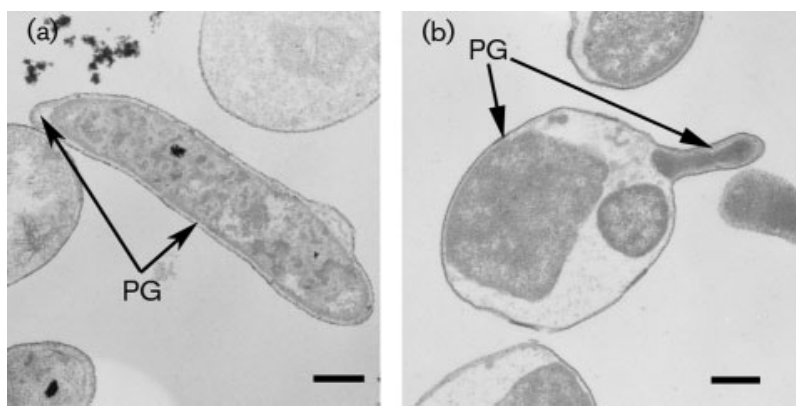

Fig. 2. Thin sections of cells of strain $M N 14^{\top}$. Cells in the early exponential phase were fixed with $2 \%$ glutaraldehyde to observe rods (a) or with $7.5 \%$ glutaraldehyde to observe spheroids (b). The structure that lines the outermost envelope containing the outer membrane (see Supplementary Fig. S1a in IJSEM Online) was assigned as peptidoglycan. PG, peptidoglycan. Bar, $500 \mathrm{~nm}$. 
membrane is an extension of the outer membrane of the rod. Note that peptidoglycan is scarce or absent in places where the outer membrane is distant from the cells.

Strain $\mathrm{MN}^{\mathrm{T}} 4^{\mathrm{T}}$ grew at $40-75{ }^{\circ} \mathrm{C}, \mathrm{pH} 5.0-8.2$ and with $0.25-5.2 \% \mathrm{NaCl}$ in Tc medium (see Supplementary Fig. S2). Optimal growth occurred at $68{ }^{\circ} \mathrm{C}, \mathrm{pH} 6.8$ and with $2.5 \% \mathrm{NaCl}$. Under these optimal conditions, the apparent doubling time was $24 \mathrm{~min}$, assuming that the strain propagated only by binary fission. Strain $\mathrm{MN}_{1} 4^{\mathrm{T}}$ is an anaerobe but could grow in the absence of added $\mathrm{Na}_{2} \mathrm{~S}$ because its metabolism rendered the culture medium anaerobic under the suboxic conditions that were generated upon inoculation. Elemental sulfur enhanced growth but was not essential for growth. Other electron acceptors, such as $\mathrm{Na}_{2} \mathrm{~S}_{2} \mathrm{O}_{3}(20 \mathrm{mM}), \mathrm{Fe}_{2} \mathrm{O}_{3}\left(4.6 \mathrm{mg} \mathrm{m}^{-1}\right)$ and $\mathrm{NaNO}_{3}(20 \mathrm{mM})$, were tested in Tc medium devoid of elemental sulfur. None of these electron acceptors enhanced growth, although reduction of $\mathrm{Fe}_{2} \mathrm{O}_{3}$ to $\mathrm{Fe}$ (II) was detected using ferrozine (Sørensen, 1982). Thiosulfatedependent sulfide production was not detected by the methylene blue method (Chen \& Mortenson, 1977). Growth substrates that could be utilized by strain MN14 ${ }^{\mathrm{T}}$ were examined by replacing yeast extract and tryptone in the Tc medium with one of the following nutrients at $0.5 \%$ $(\mathrm{w} / \mathrm{v})$ : yeast extract, tryptone, Casamino acids (supplemented with $0.1 \%$ each asparagine, glutamine and tryptophan), starch, D-glucose, maltose, cellobiose, Dfructose and D-galactose. Only yeast extract supported growth. In the presence of $0.03 \%$ yeast extract, tryptone and starch enhanced growth but the other organics did not. Glucose is a known growth substrate of all recognized species of the genus Thermosipho. However, it did not enhance the growth of strain $\mathrm{MN} 14^{\mathrm{T}}$ even when the yeast extract concentration was increased to $0.2 \%$. The headspace gas mixture of $\mathrm{H}_{2}: \mathrm{CO}_{2}(80: 20)$ did not inhibit the growth of strain $\mathrm{MN} 14^{\mathrm{T}}$ in Tc medium, but inhibition was observed when elemental sulfur was absent. This gas mixture did not support autotrophic growth of strain $\mathrm{MN} 14^{\mathrm{T}}$ in Tc medium devoid of yeast extract and tryptone.

Strain $\mathrm{MN} 14^{\mathrm{T}}$ was sensitive to novobiocin, chloramphenicol and streptomycin at $0.01 \mathrm{mg} \mathrm{ml}^{-1}$ and to rifampicin and tetracycline at $0.1 \mathrm{mg} \mathrm{ml}^{-1}$. Only spheroids grew in the presence of vancomycin $\left(0.1 \mathrm{mg} \mathrm{m}^{-1}\right)$, an inhibitor of peptidoglycan biosynthesis, suggesting that peptidoglycan biosynthesis is not required for spheroid growth.

Fatty acid methyl esters from the cells in the stationary phase exhibited two components with retention factor values of 0.62 and 0.50 on TLC with a silica gel plate (60HPTLC; Merck). They were assigned as monocarboxylic fatty acid methyl ester $(19 \%)$ and dicarboxylic fatty acid dimethyl ester (81\%), respectively, on referring to literature (Huber et al., 1989; Takai \& Horikoshi, 2000). Molecular species of monocarboxylic fatty acid methyl esters were analysed using an SP-2560 capillary column. The results suggest that the fatty acid composition was as follows: $6.4 \% \mathrm{C}_{14: 0}, 0.3 \%$ iso- $\mathrm{C}_{15: 0}, 0.3 \%$ anteiso- $\mathrm{C}_{15: 0}$, $9.9 \% \mathrm{C}_{15: 0}, 1.2 \%$ iso- $\mathrm{C}_{16: 0}, 70.1 \% \mathrm{C}_{16: 0}, 1.2 \%$ iso- $\mathrm{C}_{17: 0}$, $1.0 \%$ anteiso- $\mathrm{C}_{17: 0}, 4.7 \% \mathrm{C}_{17: 0}, 0.4 \%$ iso- $\mathrm{C}_{18: 0}, 1.9 \%$ $\mathrm{C}_{18: 0}$ and $0.9 \%$ anteiso- $\mathrm{C}_{19: 0}$.

The G $+\mathrm{C}$ content of the genomic DNA of strain MN14 ${ }^{\mathrm{T}}$ was $31.7 \mathrm{~mol} \%$. An almost complete sequence (1432 bp) of the 16S rRNA gene was determined and deposited in the DNA Data Bank of Japan (DDBJ). A basic local alignment search tool (BLAST) search (Altschul et al., 1997) for similar sequences revealed that the novel strain belonged to the genus Thermosipho. The similarities in the 16S rRNA gene of the novel strain with those of T. africanus (Huber et al.,

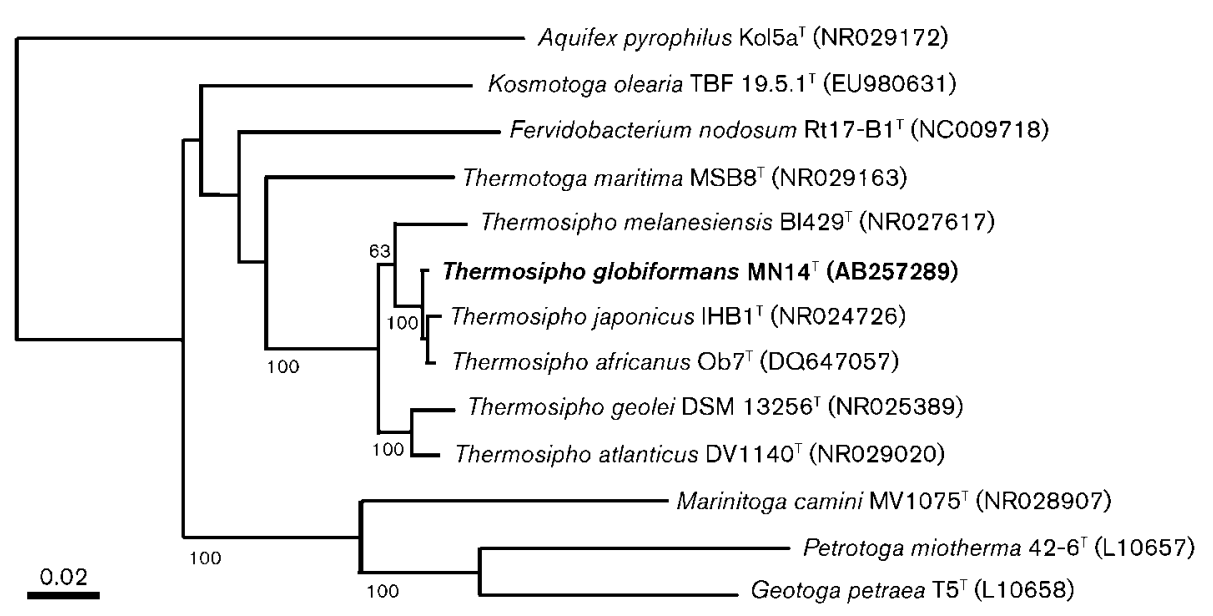

Fig. 3. Phylogenetic tree showing the position of strain MN14 $4^{\top}$. The $16 \mathrm{~S}$ rRNA gene sequences were obtained from the GenBank/EMBL/DDBJ database. Multiple alignment for a 1378 bp region was performed using the CLUSTAL W program (Thompson et al., 1994). The phylogenetic tree was constructed by the neighbour-joining method (Saitou \& Nei, 1987) with Aquifex pyrophilus $\mathrm{Kol}^{5} \mathrm{a}^{\top}$ as an outgroup. Bootstrap values $>60 \%$ in 1000 resamplings are shown on the tree. Bar, 0.02 substitutions per sequence position. 
Table 1. Characteristics that distinguish strain $M N 14^{\top}$ from other species of the genus Thermosipho

Species: 1, strain MN14 (data from present study); 2, T. africanus (Huber et al., 1989; Ravot et al., 1996); 3, T. melanesiensis (Antoine et al., 1997); 4, T. japonicus (Takai \& Horikoshi, 2000); 5, T. geolei (L'Haridon et al., 2001); 6, T. atlanticus (Urios et al., 2004). +, Positive; -, negative; (+Y), in the presence of yeast extract; $(+C)$, in the presence of casein.

\begin{tabular}{|c|c|c|c|c|c|c|}
\hline Characteristic & 1 & 2 & 3 & 4 & 5 & 6 \\
\hline DNA G $+C$ content $(\mathrm{mol} \%)$ & 31.7 & 30 & 30.5 & 31.4 & 30 & 33 \\
\hline \multicolumn{7}{|l|}{ Growth optima } \\
\hline Temperature $\left({ }^{\circ} \mathrm{C}\right)$ & 68 & 75 & 70 & 72 & 70 & 65 \\
\hline $\mathrm{pH}$ & 6.8 & 7.2 & $6.5-7.5$ & $7.2-7.6$ & 7.5 & 6.0 \\
\hline Doubling time at optimum (min) & 24 & 35 & 100 & 45 & 115 & 72 \\
\hline \multicolumn{7}{|l|}{ Growth substrate } \\
\hline Glucose & - & $(+\mathrm{Y})+$ & $(+\mathrm{Y})+$ & $(+\mathrm{Y})+$ & $(+\mathrm{Y})+$ & $(+\mathrm{Y})+$ \\
\hline Maltose & - & $(+\mathrm{Y})+$ & $(+\mathrm{Y})+$ & $(+\mathrm{Y})+$ & - & - \\
\hline Starch & $(+\mathrm{Y})+$ & $(+\mathrm{Y})+$ & $(+\mathrm{Y})+$ & $(+\mathrm{C})+$ & - & $(+\mathrm{Y})+$ \\
\hline \multicolumn{7}{|c|}{ Stimulation of growth by electron acceptor } \\
\hline Elemental sulfur & + & + & + & + & + & - \\
\hline Thiosulfate & - & + & - & + & - & - \\
\hline
\end{tabular}

1989) and T. japonicus (Takai \& Horikoshi, 2000) were $99.3 \%$ and $99.1 \%$, respectively. The gene sequence similarities with those of the other three species of the genus Thermosipho were below $96 \%$. A phylogenetic tree indicating the position of strain $\mathrm{MN} 14^{\mathrm{T}}$ is shown in Fig. 3.

The phylogenetic status of strain $\mathrm{MN} 14^{\mathrm{T}}$ with respect to $T$. africanus (Huber et al., 1989) and T. japonicus (Takai \& Horikoshi, 2000) was assessed by DNA-DNA hybridization. When the DNA of strain $\mathrm{MN}_{14}{ }^{\mathrm{T}}$ was labelled, the DNA-DNA hybridization level for both T. africanus and $T$. japonicus was found to be $43 \%$. When the DNA of $T$. africanus or T. japonicus was labelled, the level of DNADNA hybridization for strain $\mathrm{MN}_{14}{ }^{\mathrm{T}}$ was $46 \%$ or $45 \%$, respectively. The low levels of DNA hybridization strongly suggested that strain $\mathrm{MN} 14^{\mathrm{T}}$ represents a novel species (Wayne et al., 1987).

Strain $\mathrm{MN}^{\mathrm{T}}{ }^{\mathrm{T}}$ was distinguishable from $T$. africanus (Huber et al., 1989; Ravot et al., 1996) and T. japonicus (Takai \& Horikoshi, 2000) by its inability to utilize glucose and thiosulfate as a growth substrate and an electron acceptor, respectively (Table 1). Based on the low DNADNA hybridization values and the above-mentioned phenotypic differences, we propose that strain $\mathrm{MN} 14^{\mathrm{T}}$ represents a novel species belonging to the genus Thermosipho. We propose the name Thermosipho globiformans sp. nov. based on the formation of multicellular and reproductive spheroids.

\section{Description of Thermosipho globiformans sp. nov.}

Thermosipho globiformans (glo.bi.for.mans. L. n. globus sphere, globe; L. part. adj. formans forming; N.L. part. adj. globiformans globe forming).

Cells are rod-shaped and surrounded by a toga. The rods are Gram-negative staining, non-motile without flagella, 2$4 \mu \mathrm{m}$ long and $0.5 \mu \mathrm{m}$ wide and divide by binary fission. A population of rods transforms to multicellular spheroids in early growth phases owing to a defect in peptidoglycan formation. The spheroids grow to contain intensely epifluorescent globular and transformed cells, and eventually produce tiny cells in the periplasmic space. Growth occurs over a temperature range of $40-75{ }^{\circ} \mathrm{C}$ (optimum, $68{ }^{\circ} \mathrm{C}$ ), $\mathrm{pH}$ range of 5.0-8.2 (optimum, $\mathrm{pH} 6.8$ ) and in the presence of $0.25-5.2 \%(\mathrm{w} / \mathrm{v}) \mathrm{NaCl}$ (optimum, $2.5 \%$ ). The shortest doubling time is $24 \mathrm{~min}$. Anaerobic. Obligate chemo-organotroph. Grows on yeast extract as the sole growth substrate. Uses tryptone and starch in the presence of yeast extract. Uses elemental sulfur, but not thiosulfate, as an electron acceptor for growth.

The type strain MN14 ${ }^{\mathrm{T}}$ (=JCM $15059^{\mathrm{T}}=\mathrm{DSM} 19918^{\mathrm{T}}$ ) was isolated from a hydrothermal vent at Suiyo Seamount $\left(28^{\circ} 34^{\prime} \mathrm{N} 140^{\circ} 38^{\prime} \mathrm{E}\right)$ at a depth of $1384 \mathrm{~m}$ by using an in situ cultivation device that artificially creates interfaces between anaerobic and aerobic environments. The DNA $\mathrm{G}+\mathrm{C}$ content of the type strain is $31.7 \mathrm{~mol} \%$.

\section{Acknowledgements}

We thank the captain and crew of R/V Natsushima, the HyperDolphin team and the members of the Archaean Park Project for their help in sampling.

\section{References}

Altschul, S. F., Madden, T. L., Schäffer, A. A., Zhang, J., Zhang, Z., Miller, W. \& Lipman, D. J. (1997). Gapped BLAST and PSI-BLAST: a new generation of protein database search programs. Nucleic Acids Res 25, 3389-3402.

Antoine, E., Cilia, V., Meunier, J. R., Guezennec, J., Lesongeur, F. \& Barbier, G. (1997). Thermosipho melanesiensis sp. nov., a new thermophilic anaerobic bacterium belonging to the order Thermotogales, isolated from deep-sea hydrothermal vents in the southern Pacific Ocean. Int J Syst Bacteriol 47, 1118-1123. 
Balch, W. E., Fox, G. E., Magrum, L. J., Woese, C. R. \& Wolfe, R. S. (1979). Methanogens: reevaluation of a unique biological group. Microbiol Rev 43, 260-296.

Bendezú, F. O. \& de Boer, P. A. J. (2008). Conditional lethality, division defects, membrane involution, and endocytosis in mre and mrd shape mutants of Escherichia coli. J Bacteriol 190, 1792-1811.

Chen, J.-S. \& Mortenson, L. E. (1977). Inhibition of methylene blue formation during determination of the acid-labile sulfide of ironsulfur protein samples containing dithionite. Anal Biochem 79, 157165.

Elbanna, K., Lütke-Eversloh, T., Van Trappen, S., Mergaert, J., Swings, J. \& Steinbüchel, A. (2003). Schlegelella thermodepolymerans gen. nov., sp. nov., a novel thermophilic bacterium that degrades poly(3-hydroxybutyrate-co-3-mercaptopropionate). Int J Syst Evol Microbiol 53, 1165-1168.

Fiala, G. \& Stetter, K. O. (1986). Pyrococcus furiosus sp. nov. represents a novel genus of marine heterotrophic archaebacteria growing optimally at $100^{\circ} \mathrm{C}$. Arch Microbiol 145, 56-61.

Huber, R. \& Stetter, K. O. (1992). The order Thermotogales. In The Prokaryotes, pp. 3809-3815. Edited by A. Balows, H. G. Trüper, M. Dworkin, W. Harder \& K. H. Schleifer. New York: Springer.

Huber, R., Woese, C. R., Langworthy, T. A., Fricke, H. \& Stetter, K. O. (1989). Thermosipho africanus gen. nov., represents a new genus of thermophilic eubacteria within the "Thermotogales". Syst Appl Microbiol 12, 32-37.

Huber, R., Woese, C. R., Langworthy, T. A., Kristjansson, J. K. \& Stetter, K. O. (1990). Fervidobacterium islandicum sp. nov., a new extremely thermophilic eubacterium belonging to the "Thermotogales". Arch Microbiol 154, 105-111.

Katayama-Fujimura, Y., Komatsu, Y., Kuraishi, H. \& Kaneko, T. (1984). Estimation of DNA base composition by high performance liquid chromatography of its nuclease P1 hydrolysate. Agric Biol Chem 48, 3169-3172.

Kim, M. K., Im, W.-T., Shin, Y. K., Lim, J. H., Kim, S.-H., Lee, B. C., Park, M.-Y., Lee, K.-Y. \& Lee, S.-T. (2004). Kaistella koreensis gen. nov., sp. nov., a novel member of the Chryseobacterium-Bergeyella-Riemerella branch. Int J Syst Evol Microbiol 54, 2319-2324.

Kuwabara, T., Minaba, M., Iwayama, Y., Inouye, I., Nakashima, M., Marumo, K., Maruyama, A., Sugai, A., Itoh, T. \& other authors (2005). Thermococcus coalescens sp. nov., a cell-fusing hyperthermophilic archaeon from Suiyo Seamount. Int J Syst Evol Microbiol 55, 25072514.

Kuwabara, T., Minaba, M., Saida, H., Urabe, T. \& Kamekura, M. (2006). A novel in situ cultivation device for isolation of thermophilic anaerobes of deep-sea hydrothermal vents. Biosystem Studies 9, 218 227.

Kuwabara, T., Minaba, M., Ogi, N. \& Kamekura, M. (2007). Thermococcus celericrescens sp. nov., a fast-growing and cell-fusing hyperthermophilic archaeon from a deep-sea hydrothermal vent. Int $J$ Syst Evol Microbiol 57, 437-443.

L'Haridon, S. L., Miroshnichenko, M. L., Hippe, H., Fardeau, M.-L., Bonch-Osmolovskaya, E., Stackebrandt, E. \& Jeanthon, C. (2001). Thermosipho geolei sp. nov., a thermophilic bacterium isolated from a continental petroleum reservoir in Western Siberia. Int J Syst Evol Microbiol 51, 1327-1334.

Lane, D. J., Pace, B., Olsen, G. J., Stahl, D. A., Sogin, M. L. \& Pace, N. R. (1985). Rapid determination of $16 \mathrm{~S}$ ribosomal RNA sequences for phylogenetic analyses. Proc Natl Acad Sci U S A 82, 6955-6959.

Nelson, K. E., Clayton, R. A., Gill, S. R., Gwinn, M. L., Dodson, R. J., Haft, D. H., Hickey, E. K., Peterson, J. D., Nelson, W. C. \& other authors (1999). Evidence for lateral gene transfer between Archaea and bacteria from genome sequence of Thermotoga maritima. Nature 399, 323-329.

Nesbø, C. L., Bapteste, E., Curtis, B., Dahle, H., Lopez, P., Macleod, D., Dlutek, M., Bowman, S., Zhaxybayeva, O. \& other authors (2009). The genome of Thermosipho africanus TCF52B: lateral genetic connections to the Firmicutes and Archaea. J Bacteriol 191, 1974-1978.

Ravot, G., Ollivier, B., Patel, B. K. C., Magot, M. \& Garcia, J.-L. (1996). Emended description of Thermosipho africanus as a carbohydratefermenting species using thiosulfate as an electron acceptor. Int J Syst Bacteriol 46, 321-323.

Saitou, N. \& Nei, M. (1987). The neighbor-joining method: a new method for reconstructing phylogenetic trees. Mol Biol Evol 4, 406425.

Satta, G., Fontana, R., Canepari, P. \& Botta, G. (1979). Peptidoglycan synthesis in cocci and rods of a $\mathrm{pH}$-dependent, morphologically conditional mutant of Klebsiella pneumoniae. J Bacteriol 137, 727-734.

Sørensen, J. (1982). Reduction of ferric iron in anaerobic, marine sediment and interaction with reduction of nitrate and sulfate. Appl Environ Microbiol 43, 319-324.

Takai, K. \& Horikoshi, K. (2000). Thermosipho japonicus sp. nov., an extremely thermophilic bacterium isolated from a deep-sea hydrothermal vent in Japan. Extremophiles 4, 9-17.

Thompson, J. D., Higgins, D. G. \& Gibson, T. J. (1994). CLUSTAL W: improving the sensitivity of progressive multiple sequence alignment through sequence weighting, position-specific gap penalties and weight matrix choice. Nucleic Acids Res 22, 4673-4680.

Urios, L., Cueff-Gauchard, V., Pignet, P., Postec, A., Fardeau, M.-L., Ollivier, B. \& Barbier, G. (2004). Thermosipho atlanticus sp. nov., a novel member of the Thermotogales isolated from a Mid-Atlantic Ridge hydrothermal vent. Int J Syst Evol Microbiol 54, 1953-1957.

Waterbury, J. B. \& Stanier, R. Y. (1978). Patterns of growth and development in pleurocapsalean cyanobacteria. Microbiol Rev 42, 244.

Wayne, L. G., Brenner, D. J., Colwell, R. R., Grimont, P. A. D., Kandler, O., Krichevsky, M. I., Moore, L. H., Moore, W. E. C., Murray, R. G. E. \& other authors (1987). International Committee on Systematic Bacteriology. Report of the ad hoc committee on reconstitution of approaches to bacterial systematics. Int J Syst Bacteriol 37, 463-464.

Wilson, K. (2002). Preparation of genomic DNA from bacteria. In Short Protocols in Molecular Biology, 5th edn, vol. 1, Unit 2.5, pp. 1113. Edited by F. M. Ausubel, R. Brent, R. E. Kingston, D. D. Moore, J. G. Seidman, J. A. Smith \& K. Struhl. New York: Wiley.

Yoon, J.-H., Lee, S. T. \& Park, Y.-H. (1998). Inter- and intraspecific phylogenetic analysis of the genus Nocardioides and related taxa based on 16S rDNA sequences. Int J Syst Bacteriol 48, 187-194. 